
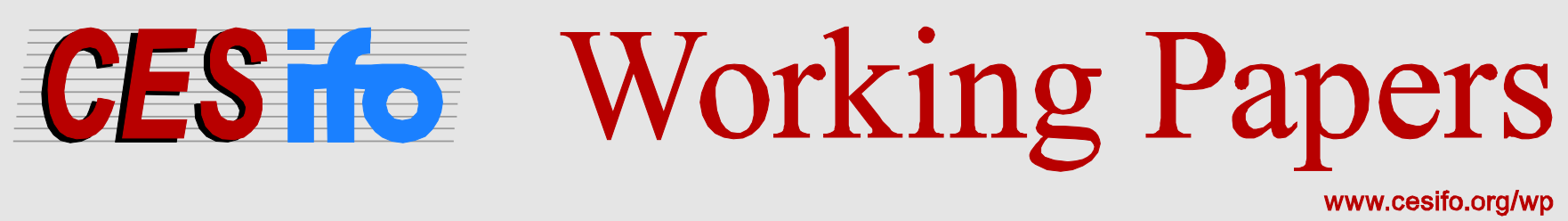

\title{
Credit Constraints and FDI Spillovers in China
}

\author{
Natasha Agarwal \\ Chris Milner \\ Alejandro Riaño
}

\section{CESIFO WORKING PAPER NO. 4313 \\ CATEgory 8: TRAde Policy \\ JUNE 2013}
An electronic version of the paper may be downloaded
- from the SSRN website:
- from the RePEc website:
- from the CESifo website:
www.SSRN.com
www.RePEc.org
www.CESifo-group.org/wp

\section{CESifo}




\title{
Credit Constraints and FDI Spillovers in China
}

\begin{abstract}
This paper examines whether credit constraints affect Chinese firms' absorption of productivity spillovers from foreign firms. Using firm-level data for 2001-2005, we find evidence of positive spillovers originating from FDI from countries other than Hong Kong, Macau and Taiwan for non-state owned Chinese firms operating in the same industry and province. Our main finding is that domestic firms operating in industries characterised by a greater reliance on external finance, our measure of credit constraints, enjoy lower (and even negative) spillovers from the activity of foreign-owned firms. This result is robust to the inclusion of a wide variety of other industry-level characteristics interacting with the activity of foreign firms.
\end{abstract}

JEL-Code: F230, G310, O100, O330.

Keywords: FDI spillovers, credit constraints, China.

\author{
Natasha Agarwal \\ Indira Gandhi Institute of Development \\ Research \\ Mumbai, Maharashtra 400065 / India \\ agarwana3@gmail.com
}

\author{
Chris Milner \\ University of Nottingham \\ Nottingham / United Kingdom \\ chris.milner@nottingham.ac.uk
}

\author{
Alejandro Riaño \\ University of Nottingham \\ Nottingham / United Kingdom \\ alejandro.riano@nottingham.ac.uk
}

June 23, 2013

We thank Sanjay Banerji, Beata Javorcik, Zuobao Wei, Zhihong Yu and seminar participants at Bournemouth University, the Indian Council for Research on International Economic Relations, Delhi, the Indira Gandhi Institute of Development Research, Mumbai, the Institute for Financial Management and Research, Chennai and participants at the ECCE-USB Conference on Financial Globalisation and Sustainable Finance for their useful comments. We would also like to thank Alessandra Guariglia for kindly providing the data to undertake this study. All remaining errors are our own. 


\section{Introduction}

In August 2012, Lenovo, the largest PC manufacturer in China, poached more than 40 laid-off employees from rival Motorola shortly after the latter announced its plan to cut 4,000 jobs globally. The main objective behind this move, according to Chen Wenhui, Lenovo's general manager of phone $\mathrm{R} \& \mathrm{D}$, was to take advantage of the former Motorola employees' vast experience in overseas markets. Similarly, Google's announcement that it was shutting down its search service Google.cn on the Chinese mainland in 2010, resulted in a rush from its Chinese competitors to hire the company's best staff. ${ }^{1}$ While a large number of Chinese companies have enjoyed the opportunity of tapping into a pool of workers trained in cutting-edge global corporations as well as adapting these firms' technology and management practices, there are still a large number of firms that are unable to take advantage of these positive external effects associated with the operation of foreign firms.

Restricted access to sources of external finance limits a firm's ability to take advantage of FDI spillovers that require costly investments such as plant retooling, improvement of output quality or worker training. ${ }^{2}$ The 2003 World Bank's Investment Climate Survey shows that privately-owned Chinese firms enjoyed much less access to formal finance than firms in any other East Asian country. Several authors have pointed at the high level of state ownership characterising China's banking system as the main reason behind this phenomenon, as a large share of credit is channeled towards state-owned enterprises to pursue political and social objectives (Brandt and Li, 2003; Cull and Xu, 2003; Allen et al., 2005). As Ayyagari et al. (2010) show, Chinese firms relying on small-scale, shorter-term sources of informal finance experience slower growth than their counterparts with access to bank credit.

In this paper we set out to investigate whether or to what extent credit constraints affect firms' ability to experience productivity spillovers engendered by the operation of foreign-owned firms. In addressing this question we seek to shed light on the conditions that enable local firms to benefit from financial globalisation. Over the past two decades China has been one of the worlds most important recipients of FDI, partly because of the size and growth of its internal market and its

\footnotetext{
${ }^{1}$ http://www . chinadaily.com.cn/business/2012-12/03/content_16054002.htm.

${ }^{2}$ Guariglia et al. (2011) and Ding et al. (2013) study how credit constraints shape firms' investment patterns in China.
} 
abundance of unskilled labour, but also because foreign firms have been enticed by a wide range of policies and incentives laid out by the Chinese government, e.g. generous fiscal schemes favouring foreign-invested enterprises and the establishment of special economic zones. The existence of positive spillovers arising as a by-product of multinational activity is frequently used to justify the use of these policies. The presence and encouragement of foreign firms, however, is necessary but not sufficient for generating spillovers from FDI; the absorptive capacity of domestic firms is also critical in determining whether the benefits of FDI spillovers are actually harnessed. Here we focus on the role of China's financial sector and its level of development and efficiency in conditioning the absorptive capacity of non-state owned Chinese firms.

Our main finding is that positive FDI spillovers do not accrue to all local firms in China. The extent of credit constraints faced by non-state owned firms condition the degree to which these firms enjoy productivity spillovers; less constrained firms reap positive gains from the presence (in the same industry and province) of foreign-owned firms while more constrained firms realise lower or even negative spillovers. Our results suggest that greater financial development targeting private firms' credit constraints would increase the size of positive FDI spillovers. This implication has wider relevance since several emerging and developing economies are seeking to emulate China's successful strategies to embrace globalisation.

Our work shares a similar focus to the body of literature that investigates whether financial development mediates the effect of FDI on economic growth at the cross-country level (Hermes and Lensink, 2003; Alfaro et al., 2004; Herzer et al., 2008; Lee and Chang, 2009). At a more disaggregated level, Javorcik and Spatareanu (2009) and Du and Girma (2007) find evidence that local firms' financial health affects their response to FDI activity across a wide range of outcomes. Javorcik and Spatareanu (2009) show that Czech firms that are less affected by liquidity constraints are more likely to self-select into becoming multinationals' suppliers. Du and Girma (2007) find that export-oriented FDI increases the likelihood of exporting for privately-owned Chinese firms, particularly those with access to bank credit, whereas domestic market-oriented FDI appears to have a negative effect on the probability of these firms starting to export. This result is similar in spirit to our finding that firms operating in industries with high external finance dependence are negatively affected by foreign activity. Our paper is also closely related to Villegas-Sanchez (2009), who finds that large firms located in more financially developed regions in Mexico enjoy greater 
productivity spillovers from FDI.

Unlike the aforementioned papers, which rely on firm-level financial indicators, we use the industry-level index of external finance dependence developed by Rajan and Zingales (1998) to identify credit constraints. ${ }^{3}$ The use of a 'frontier technology' measure, which reflects the outcome of efficient market conditions, has the attraction in this context of being exogenously determined (i.e. unaffected by local decisions) and thus helps us to overcome the endogeneity problem that might arise at the moment of identifying firms facing credit constraints. ${ }^{4}$

An important issue that arises from our empirical methodology is that our index of external finance dependence might be confounding credit constraints with other industry characteristics (e.g. capital intensity or trade openness) that also affect our measure of FDI spillovers. Nevertheless, we find that the influence of the interaction between external finance dependence and spillovers remains statistically and economically significant after the inclusion of a wide range of industry characteristics interacted with our measure of foreign firm activity. Thus giving us confidence that we are indeed capturing a relationship between credit constraints and the absorption of FDI spillovers.

The rest of the paper is organized as follows: Sections 2 and 3 describe our data and empirical methodology respectively. Our main results and robustness checks are presented in Section 4. Section 5 concludes.

\section{Data}

The data used in this study is drawn from the annual accounting reports taken from the Oriana database compiled by Bureau Van Dijk. It covers over 20,000 manufacturing firms for the period 2001-2005. The sample consists of relatively few small firms with annual sales above Yuan 1 million, and a majority of large firms with annual turnover above Yuan 5 million. The firms in our sample account for approximately $35 \%$ of total manufacturing value-added and $18 \%$ of manufacturing

\footnotetext{
${ }^{3}$ Javorcik and Spatareanu (2009) use the ratio of cash flow to total liabilities and ? the share of bank loans in total assets. Villegas-Sanchez (2009) constructs a regional ranking of financial development in Mexico based on firm-level survey responses about the main obstacles precluding firms from acquiring new machinery and equipment. Although her index of financial development is calculated at a higher level of aggregation, the concern about endogeneity remains if a larger share of highly productive firms results in more developed financial markets in a given region.

${ }^{4}$ See the surveys by Bond and Van Reenen (2007) and Strebulaev and Whited (2012) for a discussion about the econometric issues that arise when identifying credit constraints.
} 
employment in China.

The dataset contains information on value-added, employment, input costs, geographic location, sectoral affiliation and foreign ownership, distinguishing whether the source of foreign investment originates from Hong Kong, Macau and Taiwan or elsewhere. Thus, we consider a firm to be foreignowned if foreign capital participation exceeds $25 \% .^{5}$ Out of the 89,513 firm-year observations in our sample, approximately $40 \%$ are from foreign-owned enterprises. Table 1 presents the definition of all variables used in the paper and Table 2 provides summary statistics for our sample.

In order to identify credit-constrained firms in our sample, we make use of the industry-level (ISIC-3 digit) index of external finance dependence (EFD) proposed by Rajan and Zingales (1998) and made available by Braun (2003). This index is constructed as the share of capital expenditures not financed with cash flows from operation for the median publicly-listed firm in each 3-digit industry in the United States averaged over the 1980s. This index has been widely used as a proxy for the extent of financial constraints (Kroszner et al., 2007; Beck et al., 2008; Manova, 2013).

The intuition behind the use of this index is that an important component of a industry's need to access external finance is technology driven, since key determinants of the demand for external funds, such as project scale, gestation and cash harvest periods, and the requirement for continuing investment differ substantially across industries. Thus, firms operating in industries characterized by larger minimum scale requirements, longer gestation periods, higher R\&D intensity or working capital needs are more likely to face credit constraints. According to the EFD index, industries identified to be heavily reliant on external sources to finance investment include plastic products, machinery and professional equipment whereas sectors like tobacco, footwear, and clothing appear in the lower end of the ranking.

Our identification of credit constraints for Chinese firms using an industry-level index based on data for publicly-listed firms in the U.S. requires the cross-industry ranking of EFD to be stable across countries and time. The raw correlation between the EFD index based on U.S. data for the 1980s and its counterpart for Canada during the same period stands at 0.77, while the correlation between the U.S. index in the 1970s and 1980s is 0.63. Rank correlations among the three indices

\footnotetext{
${ }^{5}$ The National Bureau of Statistics of China identifies an enterprise as being foreign-funded if at least $25 \%$ of the company's registered capital is of foreign origin in the case of limited liability corporations and Chinese-foreign equity joint ventures. Exceptions include co-operative joint ventures in which the proportion of capital to be contributed by each of the parties to the venture is stipulated by contract and the wholly-foreign owned enterprises where the entire capital is invested by foreign investor(s).
} 
Table 1: Variable Description and Sources

\begin{tabular}{l}
\hline \hline Variable \\
\hline Firm Level \\
\hline Output $\left(Y_{i j p t}\right)$ \\
Capital $\left(K_{i j p t}\right)$ \\
Labour $\left(L_{i j p t}\right)$ \\
\hline Industry Level \\
\hline FDI (FDI $\left.{ }_{j p t}\right)$ \\
FDI from Other Countries $\left(\mathrm{FDI}_{j p t}^{\text {other }}\right)$ \\
FDI from Hong Kong, Macau and Tai- \\
wan (FDI $\left.{ }_{j p t}^{\mathrm{HMT}}\right)$ \\
External Financial Dependence, 1980 \\
$\left(\mathrm{EFD}_{\mathrm{US}}^{1980}\right)$
\end{tabular}

External Financial Dependence, 1970 $\left(\mathrm{EFD}_{\mathrm{US}}^{1970}\right)$ Description and Sources

External Financial Dependence, Canada $\left(\mathrm{EFD}_{\mathrm{CAN}}^{1980}\right)$

Real value added. Oriana database, Bureau Van Dijk.

Real value of tangible fixed assets. Oriana database, Bureau Van Dijk. Number of employees. Oriana database, Bureau Van Dijk.

Tangibility Index

Total value-added by foreign-owned firms within an industry-province pair in a given year. Value added of foreign firms from the Oriana database, Bureau Van Dijk.

Total value added from foreign firms originating from countries other than Hong Kong, Macau and Taiwan. Oriana database, Bureau Van Dijk.

Total value added from foreign firms originating from countries other than Hong Kong, Macau and Taiwan. Oriana database, Bureau Van Dijk.

Share of capital expenditures not financed with internal funds for the median publicly-listed U.S. firm in each 3-digit industry for the 1980s. The index is developed by Rajan and Zingales (1998) but comes from Braun (2003).

Same as above but calculated using data for the 1970s. From Braun (2003).

Same as above but calculated using data for Canadian firms for the period 1982-1990. From Rajan and Zingales (1998).

An index calculated as the median level of the ratio of net property, plant and equipment to the book value of assets of all U.S. based companies in a given industry, based on Compustat's annual industrial files for the period 1986-1995. From Braun (2003).

Capital Intensity Index

An index calculated as the median level of the ratio of fixed assets to number of employees in a given industry for U.S. Firms in Compustat for the period 1980-99. From Kroszner et al. (2007).

Liquidity Index

Durability Index

Investment Goods Producer Index

An index calculated as the median level of the ratio of inventories to sales for all active U.S.-based companies in Compustat's annual industrial files for the period 1980-99. From Kroszner et al. (2007).

An index which takes the value one if a 3-digit industry manufactures predominantly durable goods, and zero otherwise. From Kroszner et al. (2007).

The index is calculated as Investment/(Investment+Consumption) using data from 1998 BEA Input-Output table at the 3-digit industry level. This measure captures whether an industry is specialized in the production of investment goods relative to consumption goods. From Braun and Larrain (2005).

Tradability Index The index is calculated as Trade/(Trade+Domestic Use), where trade is defined as exports plus imports, and domestic use is defined as consumption plus investment, either private or public at the 3-digit industry level based on data from the BEA use tables. A value close to 1 means that the industry specializes in the production of tradable goods. From Braun and Larrain (2005).

Province Level
Deflators

Both the GDP and capital goods deflators are taken from the China Statistical Yearbook (various issues), published by the National Bureau of Statistics of China. 
Table 2: Summary Statistics

\begin{tabular}{|c|c|c|c|c|}
\hline & No. obs. & Mean & Median & Std. dev \\
\hline & \multicolumn{4}{|c|}{ Firm Level } \\
\hline & \multicolumn{4}{|c|}{ All Domestic Firms } \\
\hline Output & 47974 & 530.709 & 181.010 & 2290.911 \\
\hline Employment & 54719 & 1275.668 & 603 & 3145.504 \\
\hline \multirow[t]{2}{*}{ Capital } & 54719 & 761.010 & 173.135 & 4463.68 \\
\hline & \multicolumn{4}{|c|}{ State-Owned Domestic Firms } \\
\hline Output & 12097 & 890.562 & 250.365 & 3795.843 \\
\hline Employment & 14716 & 2220.851 & 1041 & 5314.021 \\
\hline \multirow[t]{2}{*}{ Capital } & 14716 & 1557.478 & 408.952 & 6549.014 \\
\hline & \multicolumn{4}{|c|}{ Non State-Owned Domestic Firms } \\
\hline Output & 35978 & 411.3081 & 164.022 & 1451.47 \\
\hline Employment & 40120 & 929.855 & 513 & 1645.888 \\
\hline \multirow[t]{2}{*}{ Capital } & 40120 & 471.432 & 126.433 & 3343.35 \\
\hline & \multicolumn{4}{|c|}{ Industry Level } \\
\hline$F D I_{j p t}$ & 2597 & 6714.068 & 970.700 & 23853.78 \\
\hline $\mathrm{FDI}_{j p t}^{\mathrm{other}}$ & 2229 & 5298.085 & 899.357 & 17838.71 \\
\hline $\mathrm{FDI}_{j p t}^{\mathrm{H} \mathrm{HT}}$ & 1859 & 3026.898 & 510.643 & 10424.51 \\
\hline $\mathrm{EFD}_{\mathrm{US}}^{1980}$ & 28 & 0.242 & 0.212 & 0.330 \\
\hline $\mathrm{EFD}_{\mathrm{US}}^{1970}$ & 27 & 0.043 & 0.058 & 0.177 \\
\hline $\mathrm{EFD}_{\mathrm{CAN}}^{1980}$ & 21 & 0.249 & 0.341 & 0.428 \\
\hline Tangibility Index & 28 & 0.298 & 0.291 & 0.139 \\
\hline Capital Intensity Index & 28 & 35.705 & 22.120 & 44.400 \\
\hline Liquidity Index & 28 & 0.159 & 0.155 & 0.048 \\
\hline Durability Index & 28 & 0.464 & 0 & 0.508 \\
\hline Investment Goods Producer Index & 28 & 0.178 & 0.012 & 0.271 \\
\hline Tradability Index & 28 & 0.509 & 0.495 & 0.248 \\
\hline
\end{tabular}

are all above 0.43 .

The characteristics of firms in our sample conform with the ownership and access to finance premia evidence available for other countries (Antràs and Yeaple, 2013; Campello et al., 2010). Table 3 shows that foreign-owned firms are on an average larger in terms of value-added and sales (although they are smaller in terms of employment) and more productive than their domestic counterparts. Similarly, firms producing in sectors characterized by lower external finance dependence outperform firms that are more likely to face credit constraints. Chen and Guariglia (2011) show, using balance sheet variables such as cash flow-investment sensitivities or working capital ratios to identify constrained firms, that these negatively affect the performance of Chinese firms both in terms of asset growth and productivity. 
Table 3: Firm Differences Across Ownership and External Finance Dependence

\begin{tabular}{lccccc}
\hline \multirow{2}{*}{ Mean } & \multicolumn{2}{c}{ Ownership } & & \multicolumn{2}{c}{ External Finance Dependence } \\
\cline { 2 - 3 } \cline { 5 - 6 } & Foreign & Domestic & & Below Median & Above Median \\
\hline \hline Employment & 915.2 & $1,233.3^{a}$ & & $1,273.4$ & $1,277.7$ \\
Real Value Added & 575.3 & $530.7^{a}$ & & 627.4 & $444.8^{a}$ \\
Real Sales & $2,385.4$ & $1,927.5^{a}$ & & $2,104.2$ & $1,680.7^{a}$ \\
Value Added/Employee & 0.87 & $0.57^{a}$ & & 0.61 & $0.51^{a}$ \\
TFP & 43.1 & $34.1^{a}$ & & 29.68 & $25.24^{a}$ \\
\hline Number of Firms & 8,003 & 12,967 & & 6,175 & 6,941 \\
\hline \hline
\end{tabular}

${ }^{a},{ }^{b},{ }^{c}$ mean that the variable of interest is significantly different from 0 at 1,5 and 10 percent level respectively, across the ownership and external finance dependence categories. Total Factor Productivity (TFP) is calculated using the Levinsohn and Petrin (2003) methodology.

\section{Baseline specifications and estimation methodology}

We start our analysis by estimating a Cobb-Douglas production function augmented to account for spillovers resulting from the activities of multinational firms (Harrison and Aitken, 1999; Javorcik, 2004). Our first estimating equation is:

$$
\ln Y_{i j p t}=\alpha+\beta_{K} \ln K_{i j p t}+\beta_{L} \ln L_{i j p t}+\gamma \ln \mathrm{FDI}_{j p t}+f_{i}+d_{t}+\varepsilon_{i j p t},
$$

where the subscripts $i, j, p$ and $t$ index firms, industries, provinces and years respectively. $Y_{i j p t}$ denotes real value-added and $K_{i j p t}$ and $L_{i j p t}$ are capital and labour inputs. ${ }^{6}$

We follow Feenstra et al. (2011) who argue that in the case of China it is better to estimate valueadded rather than gross output production functions due to the importance of export processing activities. To take into account the fact that productivity spillovers from FDI are more likely to be quantitatively important for firms operating in close proximity to each other within the same industry and province, we use total value-added by foreign-owned firms within an industry-province pair in a given year, $\mathrm{FDI}_{j p t}$, as our measure of FDI spillovers. This choice is founded on recent work by Girma and Gong (2008) and Abraham et al. (2010) who provide evidence that horizontal FDI spillovers are more pronounced for firms within geographical industrial clusters than just

\footnotetext{
${ }^{6}$ Firm-level value-added and our measure of FDI activity are both deflated using a provincial GDP deflator, while capital is deflated using a provincial deflator for fixed capital formation available from China's Statistical Yearbook.
} 
across firms within the same region operating across different industries. To the extent that net productivity advantages of foreign firms spills over to domestic firms, the parameter $\gamma$ would be expected to be positive; $d_{t}$ and $f_{i}$ are time and firm fixed effects; finally, $\varepsilon_{i j p t}$ is the idiosyncratic error term with iid (independently and identically distributed) properties.

The intuition behind our empirical specification is that the (potentially) more advanced technological capabilities or efficient organizational structure of foreign-owned firms gradually leaks out of the boundaries of the firm and can thus be absorbed by indigenous producers. These spillovers might take place through a variety of channels which include, but are not limited to (i) direct imitation/demonstration effects (Das, 1987; Wang and Blomstrom, 1992); (ii) tougher competition putting pressure on firms to 'trim down their fat' in order to remain in the market (Blomstrom and Kokko, 1998; Harrison and Aitken, 1999); (iii) through vertical linkages that facilitate the contact between multinational customers and domestic firms (Javorcik, 2004) and (iv) labour turnover from foreign-owned firms (Fosfuri et al., 2001). Although some of these channels might be operative through the continuous interaction between domestic and foreign firms in the product and labour markets, the focus of this paper is on whether the existence and magnitude of FDI spillovers experienced by Chinese firms is mediated by the degree of credit constraints they face. For instance, in order for a domestic producer to integrate into a multinational supply chain it might need to retool its production facilities or improve the quality of its output; similarly, attracting new personnel employed in nearby multinationals would put pressure on payroll costs. Therefore, tighter credit constraints might preclude firms from enjoying altogether any positive external effects brought about by the operation of foreign firms.

We use regression (1) not only to establish the existence of spillovers from foreign-owned firms in our sample, but also to ascertain whether the source of foreign investment and the ownership structure of local firms influence the sign and magnitude of the spillover effects. Presumably, there is a greater scope for the diffusion of productivity-enhancing knowledge from foreign-owned firms originating from developed countries than from essentially Chinese-owned firms based in Hong Kong, Macau and Taiwan (HMT) engaged in 'round-tripping' primarily to take advantage of preferential tax treatment targeted towards foreign firms (Prasad and Wei, 2007). Although it is possible that foreign firms originating in HMT might help in linking Chinese producers with foreign customers by establishing distribution links or by providing information on foreign tastes 
and preferences, since HMT are themselves home to a large number of subsidiaries of corporations based in developed countries. Thus, we re-estimate equation (1) including separately the total value-added accounted for foreign firms originating from Hong Kong, Macau and Taiwan in an industry-province cell, $\mathrm{FDI}_{j p t}^{\mathrm{HMT}}$, and the total value-added from foreign firms originating elsewhere, $\mathrm{FDI}_{j p t}^{\text {other }}$.

In a similar vein, the ownership structure of a domestic firm can importantly influence its decision to internalize potential spillovers from nearby foreign firms. For instance, state-owned enterprises (SOE) facing no budget constraints are more likely to be poorly managed and less likely to adopt innovations and managerial and organization techniques from foreign firms. ${ }^{7}$ In this case we classify domestically-owned firms in two groups: SOEs and non-state-owned enterprises, which include both privately owned firms and collective-owned enterprises, and we estimate regression (1) for each subsample. ${ }^{8}$

To investigate whether the extent of credit constraints affects the magnitude of FDI spillovers for domestically-owned Chinese firms, we augment regression (1) by introducing an interaction term between our measure of foreign activity in an industry-province cell and the industry-level index of external finance dependence described in Section 2:

$$
\ln Y_{i j p t}=\alpha+\beta_{K} \ln K_{i j p t}+\beta_{L} \ln L_{i j p t}+\gamma_{0} \ln \mathrm{FDI}_{j p t}^{\mathrm{other}}+\gamma_{1} \ln \mathrm{FDI}_{j p t}^{\mathrm{other}} \times \mathrm{EFD}_{j}+f_{i}+d_{t}+\varepsilon_{i j p t}
$$

Based on the results gathered from regression (1) which are discussed in the following section, we use as our measure of FDI spillovers the total value-added accounted for by non-HMT foreign-owned firms and we estimate regression (2) for non-state-owned domestic Chinese firms. As a robustness check we also estimate (2) using two different variants of the external finance dependence index, one calculated using U.S. data over the 1970s from Braun (2003) and the second based on data for Canadian firms between 1982 and 1990 from Rajan and Zingales (1998) respectively. We also test

\footnotetext{
${ }^{7}$ See Qian and $\mathrm{Xu}$ (1998) for a theoretical analysis of innovation under soft budget constraints and Girma and Gong (2008) for empirical evidence documenting the lack of productivity improvements among Chinese SOEs generated by multinational linkages.

${ }^{8}$ Most of the previous work in this area classifies firms according to their largest ownership type in a given year. However, according to Sun et al. (2002), the Chinese government uses a 'state ownership scheme', which means that if the assets of a SOE are not completely sold to private investors, the SOE is still not considered fully privatized and therefore still needs to conform with communism's public ownership principles. Hence, to take this feature into consideration, we identify a domestic firm to be state-owned if the paid-in-capital contributed by the state is strictly positive following Dollar and Wei (2007). The remaining firms are classified as non-state enterprises, and we allow domestic firms to switch ownership categories across years.
} 
the continuous conditioning model in (2) against a dichotomous specification where the sample is split at the median level of the EFD index and allow for differential (constant) effects above and below the threshold. ${ }^{9}$

One concern that arises when estimating (2) is that our measure of external finance dependence might be capturing other industry-specific characteristics. For instance, Braun and Larrain (2005) find that industries that are highly dependent on external finance are also characterized by large scale operation, long gestation periods, high R\&D intensity or high working capital intensity (e.g. to maintain higher inventories). Therefore, by ignoring these mechanisms, the coefficient $\gamma_{1}$ in (2) would be biased upwards. To deal with this potential omitted variable bias, we add interaction terms between our FDI variable and a set of other industry characteristics to verify that our main interaction term, $\mathrm{FDI}_{j p t}^{\text {other }} \times \mathrm{EFD}_{j}$ remains significant.

\section{Results}

Table 4 presents the estimates of regression (1). The coefficients on capital and labour are both statistically significant and their sizes are consistent with the literature. Our measure of FDI spillovers, i.e. the total value-added produced by foreign firms in a given province-industry, is positive and statistically significant at $1 \%$, which we interpret as evidence in favor of FDI spillovers. The point estimate reported in column 1 indicates that a ten percent increase in total value-added accounted by foreign firms raises the net output of domestically-owned firms operating in the same industry-province by $0.02 \%$. The size of the estimated elasticity of output with respect to foreign activity is comparable in terms of magnitude with the work of Jordaan (2005) for Mexico, and Wei and Liu (2006) and Buckley et al. (2002) for China, who find estimates of this elasticity in the range of $0.01-0.05$.

Our finding of positive and significant FDI spillovers is robust to a number of different econometric specifications presented in Appendix A. These include the addition of other time-varying firm-level characteristics such as age and export status, using a two-step methodology in which total factor productivity (TFP) is calculated in the first stage, ${ }^{10}$ and then is regressed against measures

\footnotetext{
${ }^{9}$ The unbalanced nature of our panel prevents us from using an endogenous threshold modelling approach as in Hansen (1999).

${ }^{10}$ In our case, using the algorithm developed by Levinsohn and Petrin (2003).
} 
Table 4: FDI Spillovers

\begin{tabular}{|c|c|c|c|c|c|}
\hline & \multicolumn{5}{|c|}{ Value-Added } \\
\hline & \multicolumn{3}{|c|}{ All Domestic Firms } & \multirow{2}{*}{$\begin{array}{l}\text { State- } \\
\text { Owned } \\
\text { (4) }\end{array}$} & \multirow{2}{*}{$\begin{array}{l}\text { Non } \\
\text { State- } \\
\text { Owned } \\
(5)\end{array}$} \\
\hline & (1) & (2) & (3) & & \\
\hline \multirow[t]{2}{*}{ Capital } & $0.199^{a}$ & $0.194^{a}$ & $0.194^{a}$ & $0.272^{a}$ & $0.191^{a}$ \\
\hline & $(0.011)$ & $(0.011)$ & $(0.012)$ & (0.037) & $(0.012)$ \\
\hline \multirow[t]{2}{*}{ Labour } & $0.559^{a}$ & $0.559^{a}$ & $0.564^{a}$ & $0.530^{a}$ & $0.556^{a}$ \\
\hline & $(0.018)$ & $(0.018)$ & $(0.019)$ & $(0.062)$ & $(0.019)$ \\
\hline \multirow[t]{2}{*}{ FDI } & $0.024^{a}$ & & & & \\
\hline & $(0.008)$ & & & & \\
\hline $\mathrm{FDI}^{\text {other }}$ & & $0.018^{b}$ & & 0.016 & $0.019^{b}$ \\
\hline \multirow{2}{*}{$\mathrm{FDI}^{\mathrm{HMT}}$} & & & 0.011 & & \\
\hline & & & $(0.007)$ & & \\
\hline \multirow[t]{2}{*}{ Constant } & $0.512^{a}$ & $0.604^{a}$ & $0.343^{a}$ & -0.053 & $0.673^{a}$ \\
\hline & $(0.131)$ & $(0.129)$ & $(0.130)$ & $(0.421)$ & $(0.141)$ \\
\hline No. of observations & 40,537 & 38,479 & 34,859 & 8,354 & 30,219 \\
\hline No. of firms & 11,521 & 11,135 & 10,323 & 3,020 & 9,435 \\
\hline R-squared & 0.231 & 0.230 & 0.239 & 0.147 & 0.255 \\
\hline
\end{tabular}

Robust standard errors clustered at the firm level in parenthesis. ${ }^{a},{ }^{b},{ }^{c}$ significantly different from 0 at 1,5 and 10 percent level respectively. All regressions include firm and year fixed effects. Capital is measured as the real value of tangible fixed assets. Labour is measured as the number of employees. FDI is measured as the total value-added by foreign-owned firms within an industry-province pair in a given year. $\mathrm{FDI}^{\mathrm{HMT}}$ is measured as the total value-added accounted for foreign firms originating from Hong Kong, Macau and Taiwan in an industry-province cell. FDI ${ }^{\text {other }}$ is measured as the total value-added from foreign firms not originating in HMT in an industry-province pair.

of FDI activity (Girma and Gong, 2008; Javorcik and Spatareanu, 2009; Abraham et al., 2010), the use of several arrangements of clustering the standard errors, ${ }^{11}$ and the use of production functions estimated separately at the industry-level.

We then proceed to disentangle the average net positive FDI spillovers according to their sources of origin. In particular, we investigate whether the operation of multinationals from Hong Kong, Macau and Taiwan (HMT) generate positive spillovers for domestically-owned Chinese firms. The estimates presented in columns 2 and 3 of Table 1 show that the existence of positive spillovers is mainly driven by the operation of firms with investments originating outside HMT. Based on these findings, the results reported in columns 4 and 5 also show that non-SOE firms are the ones

\footnotetext{
${ }^{11}$ Different results obtain when the standard errors are clustered using the group (industry-province) approach as compared to using Cameron et al. (2009)'s cmreg routine in Stata. This is because both approaches make different assumptions on the independence of errors across clusters. Nevertheless, given the unbalanced small number of clusters that result when clustering at industry-province level, estimates obtained using both methods should be interpreted with caution.
} 
Table 5: Credit Constraints and FDI Spillovers

\begin{tabular}{lllllll}
\hline \hline & \multicolumn{5}{c}{ Value-Added of Non State-Owned Domestic Firms Only } \\
\cline { 2 - 7 } & $\begin{array}{l}\mathrm{EFD}_{\mathrm{US}}^{1980} \\
(1)\end{array}$ & $\begin{array}{l}\mathrm{EFD}_{\mathrm{US}}^{1970} \\
\mathrm{EFD}_{\mathrm{CAN}}^{1980}\end{array}$ & $\begin{array}{l}\mathrm{EFD}_{\mathrm{US}}^{1980} \\
(3)\end{array}$ & $\begin{array}{l}\mathrm{EFD}_{\mathrm{US}}^{1970} \\
(5)\end{array}$ & $\begin{array}{l}\mathrm{EFD}_{\mathrm{CAN}}^{1980} \\
(6)\end{array}$ \\
\hline $\mathrm{FDI}^{\text {other }}$ & $0.043^{a}$ & $0.024^{b}$ & $0.059^{a}$ & $0.047^{a}$ & $0.032^{a}$ & $0.056^{a}$ \\
& $(0.012)$ & $(0.010)$ & $(0.012)$ & $(0.012)$ & $(0.012)$ & $(0.012)$ \\
$\mathrm{FDI}^{\text {other }} \times \mathrm{EFD}$ & $-0.097^{a}$ & -0.078 & $-0.136^{a}$ & & & \\
& $(0.025)$ & $(0.048)$ & $(0.026)$ & & & \\
$\mathrm{FDI}^{\text {other }} \times \mathrm{EFD}$ dummy & & & & $-0.067^{a}$ & $-0.027^{c}$ & $-0.097^{a}$ \\
& & & & $(0.016)$ & $(0.016)$ & $(0.017)$ \\
\hline No. of observations & 30,219 & 29,735 & 26,123 & 30,219 & 29,735 & 26,123 \\
No. of firms & 9,435 & 9,290 & 8,154 & 9,435 & 9,290 & 8,154 \\
R-Squared & 0.256 & 0.255 & 0.254 & 0.256 & 0.255 & 0.255 \\
\hline \hline
\end{tabular}

Robust standard errors clustered at the firm level in parenthesis. ${ }^{a},{ }^{b},{ }^{c}$ significantly different from 0 at 1,5 and 10 percent level respectively. All regressions include firm and year fixed effects. The coefficients on capital and labour are not reported to save space. FDI is measured as the total value-added by foreign-owned firms within an industry-province pair in a given year. $\mathrm{FDI}^{\text {other }}$ is measured as the total real value-added from foreign firms not originating in HMT in an industry-province cell. $\mathrm{EFD}_{\mathrm{US}}^{1980}$ is the external financial dependence index constructed as the share of capital expenditures not financed with cash flows from operation for the median publicly-listed firm in each 3-digit industry in the United States averaged over the 1980 s. EFD $_{\mathrm{US}}^{1970}$ is calculated in the same way as EFD $\mathrm{US}^{1980}$ but data is averaged over the 1970 s. Both, EFD $\mathrm{US}_{\mathrm{US}}^{1980}$ and $\mathrm{EFD}_{\mathrm{US}}^{1970}$ are developed by Rajan and Zingales (1998) and

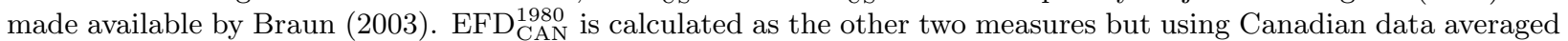
over the period 1982 and 1990. The index is developed and made available by Rajan and Zingales (1998).

benefitting the most from multinational activity. The lack of evidence of significant spillovers for state-owned firms is consistent with previous findings by Girma and Gong (2008) and Hale and Long (2011). Since we do not find evidence of productivity spillover benefits arising from foreign firms originating from HMT or accruing to state-owned firms, the remaining of the analysis will only focus on how the activity of non-HMT firms and affects the value-added of non-state-owned, domestic Chinese producers.

We now move to our main research question, i.e. does a higher degree of credit constraints prevent domestically-owned Chinese firms from experiencing positive productivity spillovers arising from FDI? Table 5 presents the estimates from regression (2). The interaction term between the activity of foreign firms in an industry-province pair and the Rajan and Zingales (1998) industrylevel measure of external finance dependence (EFD) is statistically significant, whether we use the continuous measure or a dummy variable splitting industries at the median of the EFD index; the only exception is when EFD is measured using the continuous index based on U.S. data for the 1970s, although in this case, the interaction is just marginally insignificant at the $10 \%$.

The negative sign of the coefficient associated with the interaction term means that firms 
operating in industries characterized by higher external finance requirements would benefit less from FDI spillovers than comparable firms in low-EFD industries. In fact, non-SOE firms in industries in which EFD exceeds 44\%, e.g. manufacture of electric machinery, manufacture of plastic or glass products or professional equipment, might even experience a negative impact from the operation of foreign multinationals. Using a dummy variable splitting industries at the median EFD in column 4 of Table 5 indicates the existence of positive spillovers for non-SOE domestic firms in industries with external financial dependence below the median and negative spillovers for firms operating in industries above the median EFD. The dichotomous specification is our preferred one based on the J-test proposed by Davidson and MacKinnon (1981) which rejects the linear specification in favour of the sample splitting model (refer to table A.9 in the appendix). ${ }^{12}$

These results are consistent with cross-country studies undertaken by Alfaro et al. (2004), and Hermes and Lensink (2003), as well as the work of Villegas-Sanchez (2009) for Mexico which show that countries/regions with more developed financial markets stand to gain more from FDI. Similarly, Javorcik and Spatareanu (2009) find that less credit constrained Czech manufacturing firms self-select into becoming suppliers for multinational firms.

An important issue that arises in interpreting the results from regression (2) is whether we truly are measuring cross-industry variation on the tightness of credit constraints, or, if on the other hand, we are just capturing other industry characteristics that are correlated with the activity of foreign firms.

For instance, Defever and Riaño (2012) show that local governments in China actively encourage the operation of foreign firms focused on exporting activities using fiscal incentives channeled through special economic zones. However, it is also the case that firms operating in highly tradable industries are characterised by longer delivery lags and more complex inventory management (Alessandria et al., 2010), which makes tradability strongly positively correlated with EFD at the industry level. Thus, our estimated negative coefficient for the interaction term FDI ${ }^{\text {other }} \times$ EFD might be picking up the fact that a greater level of activity by export-oriented multinationals could result in a tougher competitive environment and lower production by domestic Chinese firms. If this was indeed the case, we would expect that including an additional interaction term between

\footnotetext{
${ }^{12}$ Results reported in columns 2 and 4 of table 5 are also subject to a number of different robustness checks presented in Appendix A.
} 


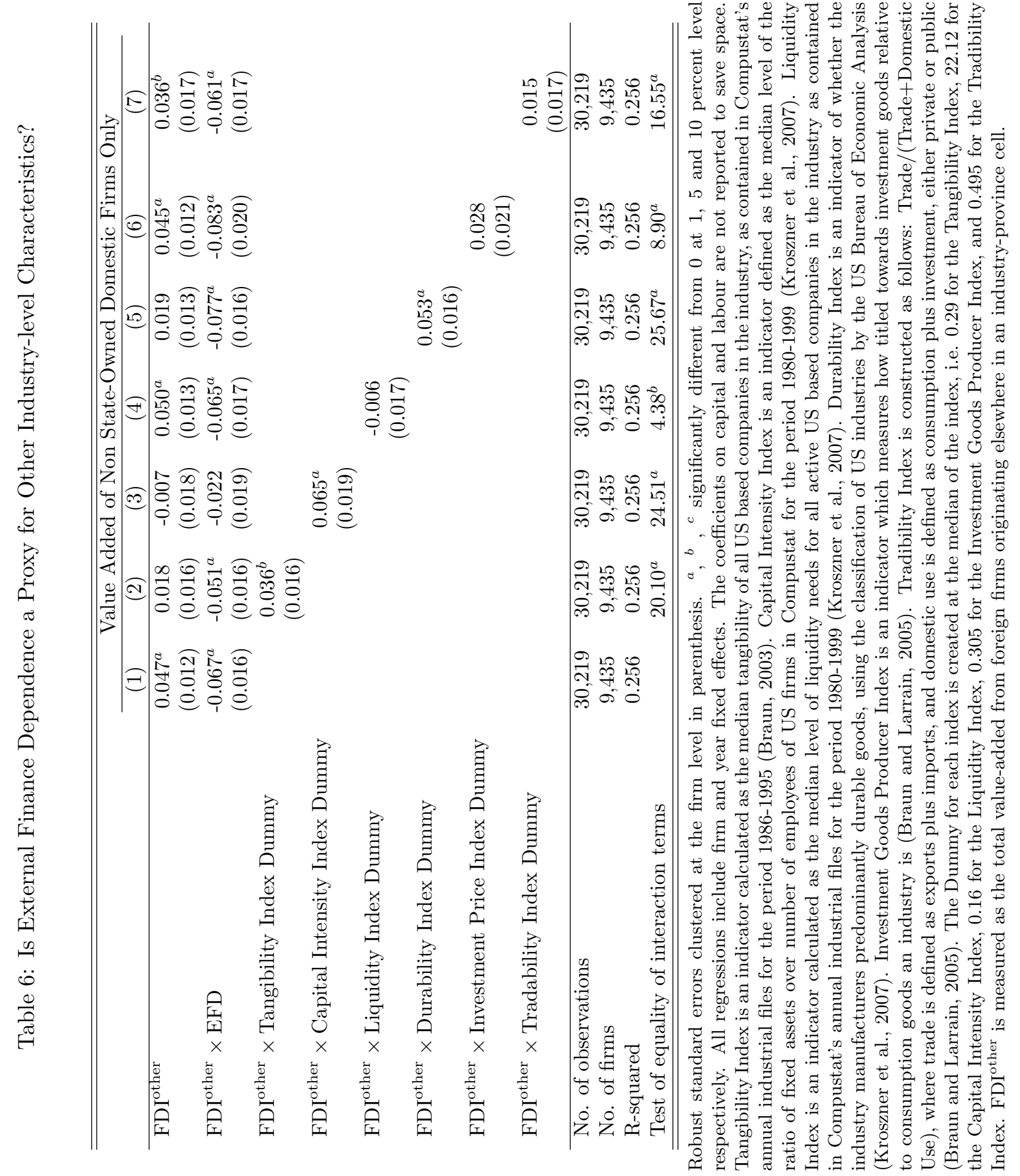


our industry-province measure of foreign activity and an industry-level index of tradability should render the coefficient of interest, $\gamma_{1}$, in regression (2) statistically insignificant.

Besides the tradability index, we conduct this robustness exercise using a wide set of indices of industry characteristics including tangibility, durability, liquidity and an indicator for industries that primarily produce investment goods drawn from Braun and Larrain (2005) and Kroszner et al. (2007), all of which are calculated using data for publicly-listed firms in the U.S., just as our index for credit constraints. ${ }^{13}$

A greater degree of tangibility, which is a measure based on the share of total assets accounted for net property, plant and equipment, should everything else equal, facilitate a firm's access to external finance as there is lower uncertainty regarding a firm's collateral. Thus, we would expect domestic Chinese firms in highly tangible industries to enjoy positive, net spillovers from nearby non-HMT multinationals in the same industry as they will be able to raise the required external finance by pledging hard assets as collateral. Similarly, we would expect firms in capital-intensive sectors, producing goods that are durable, tradable and for investment purposes to realise greater spillovers from multinational activity.

All in all, we find that our posited relationship that greater demand for external finance curtails FDI spillovers remains even after controlling for the interaction of a wide range of industry characteristics and the level of foreign activity at the province-industry level. The interaction between FDI and EFD is negative and statistically significant at the $1 \%$ level when we control for all other interaction terms one by one, with the exception of the capital-intensity term. ${ }^{14}$ The magnitude of the interaction between FDI and external finance dependence is quite similar across all our specifications. Thus, we are confident that the results presented in Table 5 reflect the fact that operating in an environment with tighter credit constraints might substantially decrease the scope for domestic firms to realise external productivity gains from the operation of foreign firms.

\footnotetext{
${ }^{13}$ The correlation between EFD and the other industry characteristics we investigate ranges from -0.0914 with respect to liquidity index to 0.3794 with investment goods producer index.

${ }^{14}$ Although the coefficient estimate on $\mathrm{FDI}^{\text {other }} \times \mathrm{EFD}$ is statistically insignificant, the test of equality of the two interaction terms shows that there are two different channels operating. Moreover, this interaction appears as statistically significant when the term FDI ${ }^{\text {other }} \times$ Capital Intensity Index Dummy is introduced as a continuous interaction term.
} 


\section{Conclusions}

Using a panel of over 20,000 Chinese manufacturing firms for the period 2001-2005, we find positive spillovers arising from the operation of multinational firms originating outside Hong Kong, Macau and Taiwan for domestic, non-state owned Chinese firms. Our main finding is that the extent of credit constraints faced by firms, measured by an industry-level index of the demand for external finance, have an important conditioning influence on the extent to which domesticallyowned Chinese firms benefit from the activity of foreign firms. This result suggests that positive productivity spillovers occurring as a by-product of the operation of multinational firms do not accrue automatically to local firms. The latter require access to formal sources of finance in order to take advantage of technological innovations, better management practices or to attract skilled employees made available by foreign-owned firms. Our results are robust to the use of different measures of credit constraints, various clustering arrangements of standard errors and controlling for other confounding factors at the sectoral level that might influence the relationship between FDI spillovers and external finance dependence.

To the best of our knowledge, this is the first paper that provides empirical support for the argument that local producers' access to external sources of finance play an important role in determining the productivity spillovers that they can obtain from foreign direct investment. This link is particularly important for China, as several authors have established that the efficiency of its financial system has lagged behind other developments in its economy. Thus, improving the access of non-state owned firms to formal sources of finance could result in important productivity gains as China is likely to remain one of the most popular recipients of foreign investment in the world. 


\section{References}

Abraham, F., J. Konings, And V. Slootmaekers (2010): "FDI spillovers in the Chinese manufacturing sector," The Economics of Transition, 18, 143-182.

Alessandria, G., J. P. Kaboski, and V. Midrigan (2010): "Inventories, lumpy trade, and large devaluations," American Economic Review, 100, 2304-39.

Alfaro, L., A. Chanda, S. Kalemli-Ozcan, And S. Sayek (2004): "FDI and economic growth: the role of local financial markets," Journal of International Economics, 64, 89-112.

Allen, F., J. Qian, And M. Qian (2005): "Law, finance, and economic growth in China," Journal of Financial Economics, 77, 57-116.

Antràs, P. And S. R. Yeaple (2013): "Multinational firms and the structure of international trade," NBER Working Papers 18775, National Bureau of Economic Research.

Ayyagari, M., A. DemirgüÇ-Kunt, and V. Maksimovic (2010): "Formal versus informal finance: evidence from China," Review of Financial Studies, 23, 3048-3097.

Beck, T., A. DemirgüÇ-Kunt, L. Laeven, and R. Levine (2008): "Finance, firm size, and growth," Journal of Money, Credit and Banking, 40, 1379-1405.

Blomstrom, M. And A. Kokko (1998): "Multinational corporations and spillovers," Journal of Economic Surveys, 12, 247-77.

Bond, S. And J. VAn ReEnen (2007): "Microeconometric models of investment and employment," in Handbook of Econometrics, ed. by J. Heckman and E. Leamer, Elsevier, vol. 6 of Handbook of Econometrics, chap. 65.

Brandt, L. AND H. Li (2003): "Bank discrimination in transition economies: ideology, information, or incentives?" Journal of Comparative Economics, 31, 387-413.

Braun, M. (2003): "Financial contractibility and asset hardness," Manuscript, University of California, Los Angeles.

Braun, M. AND B. LARRAIn (2005): "Finance and the business cycle: international, inter-industry evidence," Journal of Finance, 60, 1097-1128.

Buckley, P. J., J. ClegG, And C. WAng (2002): "The impact of inward FDI on the performance of Chinese manufacturing firms," Journal of International Business Studies, 33, 637-655.

Cameron, A. C., J. B. Gelbach, D. L. Miller, And D. Miller (2009): "Robust inference with multi-way clustering," Working Papers 98, University of California, Davis, Department of Economics.

Campello, M., J. R. Graham, and C. R. Harvey (2010): "The real effects of financial constraints: evidence from a financial crisis," Journal of Financial Economics, 97, 470-487.

Chen, M. and A. Guariglia (2011): "Financial constraints and firm productivity in China: do liquidity and export behavior make a difference?" Discussion Papers 11/09, University of Nottingham, GEP. 
Cull, R. And L. C. Xu (2003): "Who gets credit? the behavior of bureaucrats and state banks in allocating credit to Chinese state-owned enterprises," Journal of Development Economics, 71, $533-559$.

DAS, S. (1987): "Externalities, and technology transfer through multinational corporations: a theoretical analysis," Journal of International Economics, 22, 171-182.

Davidson, R. And J. G. MacKinnon (1981): "Several tests for model specification in the presence of alternative hypotheses," Econometrica, 49, 781-93.

Defever, F. And A. Riaño (2012): "China's pure exporter subsidies," CEP Discussion Papers 1182.

Ding, S., A. Guariglia, And J. Knight (2013): "Investment and financing constraints in China: does working capital management make a difference?" Journal of Banking 8 F Finance, 37, 1490-1507.

Dollar, D. And S.-J. WeI (2007): "Das (Wasted) Kapital: firm ownership and investment efficiency in China," NBER Working Papers 13103, National Bureau of Economic Research.

Du, J. And S. Girma (2007): "Finance and Firm Export in China," Kyklos, 60, 37-54.

Feenstra, R. C., Z. Li, And M. Yu (2011): "Exports and credit constraints under incomplete information: theory and evidence from China," NBER Working Papers 16940.

Fosfuri, A., M. Motta, And T. Ronde (2001): "Foreign direct investment and spillovers through workers' mobility," Journal of International Economics, 53, 205-222.

Girma, S. AND Y. Gong (2008): "FDI, linkages and the efficiency of state-owned enterprises in China," Journal of Development Studies, 44, 728-749.

Guariglia, A., X. Liu, And L. Song (2011): "Internal finance and growth: Microeconometric evidence on Chinese firms," Journal of Development Economics, 96, 79-94.

Hale, G. And C. Long (2011): "Are there productivity spillovers from foreign direct investment in China?" Pacific Economic Review, 16, 135-153.

Hansen, B. E. (1999): "Threshold effects in non-dynamic panels: estimation, testing, and inference," Journal of Econometrics, 93, 345-368.

Harrison, A. E. And B. J. Aitken (1999): "Do domestic firms benefit from direct foreign investment? evidence from Venezuela," American Economic Review, 89, 605-618.

Hermes, N. And R. Lensink (2003): "Foreign direct investment, financial development and economic growth," Journal of Development Studies, 40, 142-163.

Herzer, D., S. Klasen, And F. Nowak-Lehmann (2008): "In search of FDI-led growth in developing countries: the way forward," Economic Modelling, 25, 793-810.

JAVORCIK, B. S. (2004): "Does foreign direct investment increase the productivity of domestic firms? in search of spillovers through backward linkages," American Economic Review, 94, 605627. 
Javorcik, B. S. and M. Spatareanu (2009): "Liquidity Constraints and Firms' Linkages with Multinationals," World Bank Economic Review, 23, 323-346.

JordaAn, J. A. (2005): "Determinants of FDI-induced externalities: New empirical evidence for Mexican manufacturing industries," World Development, 33, 2103-2118.

Kroszner, R. S., L. Laeven, And D. Klingebiel (2007): "Banking crises, financial dependence, and growth," Journal of Financial Economics, 84, 187-228.

LeE, C.-C. And C.-P. Chang (2009): "FDI, financial development, and economic growth: International evidence," Journal of Applied Economics, 0, 249-271.

Levinsohn, J. And A. Petrin (2003): "Estimating production functions using inputs to control for unobservables," Review of Economic Studies, 70, 317-341.

Manova, K. (2013): "Credit constraints, heterogeneous firms, and international trade," Review of Economic Studies, 80, 711-744.

Prasad, E. AND S.-J. WEI (2007): "The Chinese approach to capital inflows: patterns and possible explanations," in Capital Controls and Capital Flows in Emerging Economies: Policies, Practices and Consequences, National Bureau of Economic Research, 421-480.

QIAN, Y. AND C. XU (1998): "Innovation and bureaucracy under soft and hard budget constraints," Review of Economic Studies, 65, 151-164.

Rajan, R. G. And L. Zingales (1998): "Financial dependence and growth," American Economic Review, 88, 559-86.

Strebulaev, I. A. And T. M. Whited (2012): "Dynamic models and structural estimation in corporate finance," Manuscript, University of Rochester.

Sun, Q., W. H. S. Tong, And J. Tong (2002): "How does government ownership affect firm performance? evidence from China's privatization experience," Journal of Business Finance $\mathcal{E}$ Accounting, 29, 1-27.

Villegas-SAnChez, C. (2009): "FDI spillovers and the role of local financial markets: evidence from Mexico," Manuscript, University of Houston.

Wang, J.-Y. And M. Blomstrom (1992): "Foreign investment and technology transfer : A simple model," European Economic Review, 36, 137-155.

WEI, Y. AND X. LiU (2006): "Productivity spillovers from R\&D, exports and FDI in China's manufacturing sector," Journal of International Business Studies, 37, 544-557. 


\section{A Appendix}

Table A.1: FDI Spillovers: Robustness to Time-Varying Firm Characteristics

\begin{tabular}{lllll}
\hline \hline & \multicolumn{4}{l}{ Value-Added of Domestic Firms Only } \\
\cline { 2 - 5 } & $(1)$ & $(2)$ & $(3)$ & $(4)$ \\
\hline Capital & $0.199^{a}$ & $0.198^{a}$ & $0.200^{a}$ & $0.198^{a}$ \\
Labour & $(0.011)$ & $(0.011)$ & $(0.011)$ & $(0.011)$ \\
& $0.559^{a}$ & $0.552^{a}$ & $0.559^{a}$ & $0.551^{a}$ \\
FDI & $(0.018)$ & $(0.018)$ & $(0.018)$ & $(0.018)$ \\
& $0.024^{a}$ & $0.024^{a}$ & $0.024^{a}$ & $0.024^{a}$ \\
Export Dummy & $(0.008)$ & $(0.008)$ & $(0.008)$ & $(0.008)$ \\
& & $0.100^{a}$ & & $0.100^{a}$ \\
Age & & $(0.016)$ & & $(0.016)$ \\
& & & 0.046 & 0.046 \\
Constant & & & $(0.039)$ & $(0.039)$ \\
& $0.512^{a}$ & $0.524^{a}$ & $0.508^{a}$ & $0.520^{a}$ \\
\hline No. of observations & 40,537 & 40,537 & 40,513 & $(0.131)$ \\
No. of firms & 11,521 & 11,521 & 11,519 & 11,519 \\
R-Squared & 0.231 & 0.232 & 0.230 & 0.232 \\
\hline \hline
\end{tabular}

Robust standard errors clustered at the firm level in parenthesis. ${ }^{a},{ }^{b},{ }^{c}$ significantly different from 0 at 1,5 and 10 percent level respectively. All regressions include firm and year fixed effects. Capital is measured as the real value of tangible fixed assets. Labour is measured as the number of employees. FDI is measured as the total value-added by foreign-owned firms within an industry-province pair in a given year.

Table A.2: FDI Spillovers: Robustness to Alternative Dependent Variable

\begin{tabular}{lll}
\hline \hline & \multicolumn{2}{c}{ Domestic Firms Only } \\
\cline { 2 - 3 } & $\begin{array}{l}\text { Value Added } \\
\text { Capital }\end{array}$ & \multicolumn{1}{c}{ Total Factor Productivity } \\
\hline \multirow{2}{*}{ Labour } & $0.199^{a}$ & \\
& $(0.011)$ & \\
FDI & $0.559^{a}$ & \\
& $(0.024)$ & \\
Constant & $0.024^{a}$ & $0.026^{a}$ \\
& $(0.008)$ & $(0.008)$ \\
No. of observations & $0.512^{a}$ & $2.719^{a}$ \\
No. of firms & $(0.131)$ & $(0.075)$ \\
R-Squared & 10,537 & 40,537 \\
\hline \hline
\end{tabular}

Robust standard errors clustered at the firm level in parenthesis. ${ }^{a},{ }^{b},{ }^{c}$ significantly different from 0 at 1,5 and 10 percent level respectively. All regressions include firm and year fixed effects. Capital is measured as the real value of tangible fixed assets. Labour is measured as the number of employees. FDI is measured as the total value-added by foreign-owned firms within an industry-province pair in a given year. Total Factor Productivity is calculated using the Levinsohn and Petrin (2003) approach. 
Table A.3: FDI Spillovers: Robustness to Clustering of Standard Errors at Different Levels

\begin{tabular}{llll}
\hline \hline \multirow{2}{*}{ Standard Errors Clustered at: } & \multicolumn{3}{c}{ Value-Added of Domestic Firms Only } \\
\cline { 2 - 4 } & $(1)$ & $(2)$ & Industry-Province \\
Capital & $0.199^{a}$ & $0.199^{a}$ & $0.188^{a}$ \\
& $(0.011)$ & $(0.011)$ & $(0.015)$ \\
Labour & $0.559^{a}$ & $0.559^{a}$ & $0.568^{a}$ \\
& $(0.018)$ & $(0.018)$ & $(0.042)$ \\
FDI & $0.024^{a}$ & $0.024^{c}$ & 0.023 \\
& $(0.008)$ & $(0.013)$ & $(0.020)$ \\
Constant & $0.512^{a}$ & $0.512^{a}$ & -0.000 \\
& $(0.131)$ & $(0.175)$ & $(0.000)$ \\
\hline No. of observations & 40,537 & 40,537 & 32,801 \\
No. of firms & 11,521 & 11,521 & - \\
R-Squared & 0.231 & 0.231 & 0.24 \\
\hline \hline
\end{tabular}

Robust standard errors clustered at the firm level in parenthesis. ${ }^{a},{ }^{b},{ }^{c}$ significantly different from 0 at 1,5 and 10 percent level respectively. All regressions include firm and year fixed effects. Results reported in column 3 is estimated using cgmreg command in Stata. Results reported in column 2 are estimated by creating groups of industryprovince to cluster the standard errors. Capital is measured as the real value of tangible fixed assets. Labour is measured as the number of employees. FDI is measured as the total value-added by foreign-owned firms within an industry-province pair in a given year.

Table A.4: FDI Spillovers: Robustness to Varying Production Function For All Industries

\begin{tabular}{ll}
\hline \hline & Value-Added of Domestic Firms Only \\
\cline { 2 - 2 } Capital & $(1)$ \\
& 0.504 \\
Labour & $(0.326)$ \\
& $0.516^{c}$ \\
FDI & $(0.277)$ \\
& $0.022^{a}$ \\
Constant & $(0.008)$ \\
& $0.51^{a}$ \\
No. of observations & $(0.13)$ \\
No. of firms & 40,537 \\
R-Squared & 11,521 \\
\hline \hline
\end{tabular}

Robust standard errors clustered at the firm level in parenthesis. ${ }^{a},{ }^{b},{ }^{c}$ significantly different from 0 at 1,5 and 10 percent level respectively. All regressions include firm, year, industry $\times$ capital, and industry $\times$ labour fixed effects. Capital is measured as the real value of tangible fixed assets. Labour is measured as the number of employees. FDI is measured as the total value-added by foreign-owned firms within an industry-province pair in a given year. 


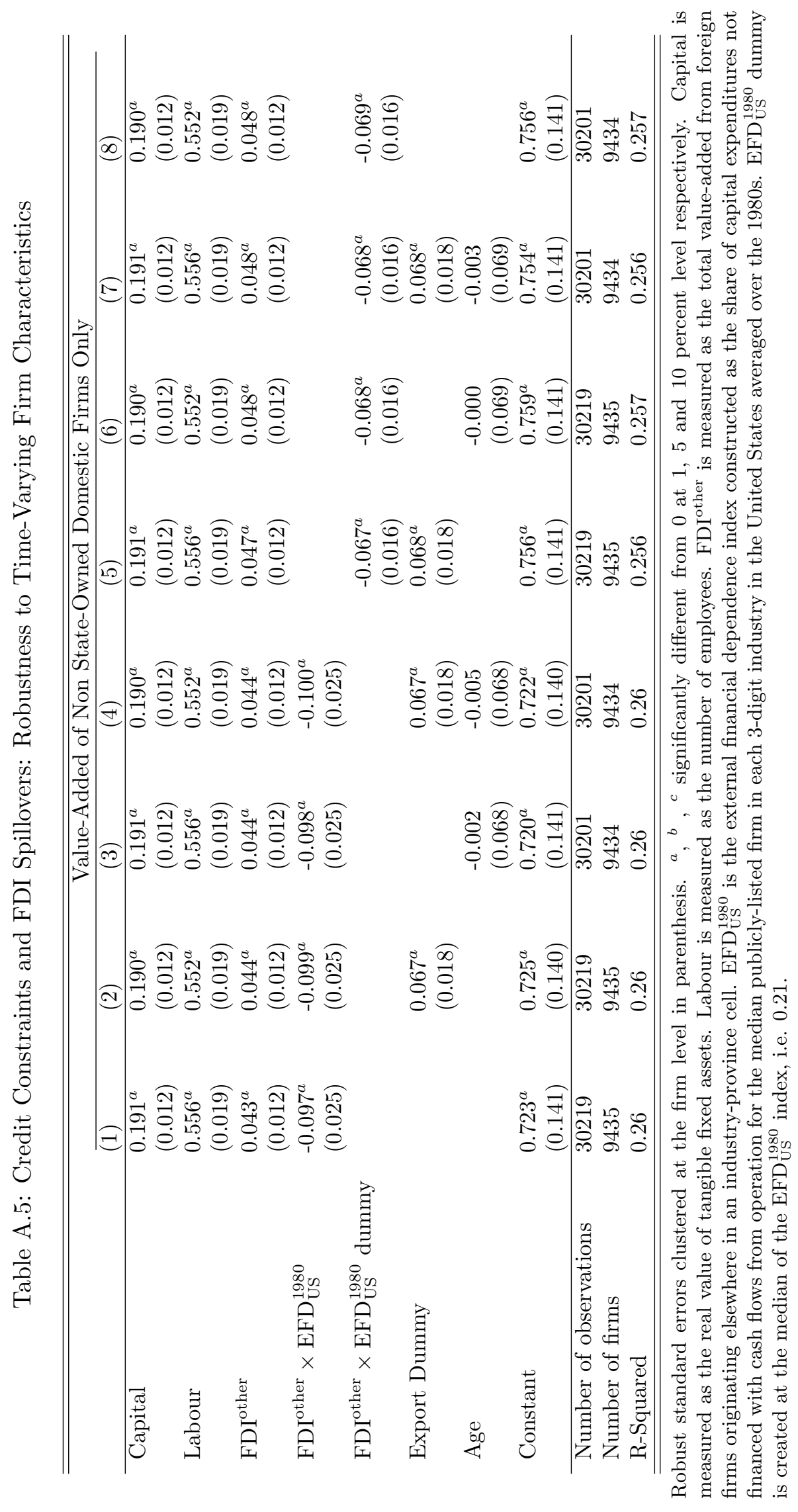


Table A.6: Credit Constraints and FDI Spillovers: Robustness to Alternative Dependent Variable

\begin{tabular}{|c|c|c|c|c|}
\hline & \multicolumn{4}{|c|}{ Non State-Owned Domestic Firms Only } \\
\hline & \multicolumn{2}{|c|}{ Value Added } & \multicolumn{2}{|c|}{ Total Factor Productivity } \\
\hline & $(1)$ & $(2)$ & $(3)$ & $(4)$ \\
\hline \multirow[t]{2}{*}{ Capital } & $0.191^{a}$ & $0.191^{a}$ & & \\
\hline & $(0.012)$ & $(0.012)$ & & \\
\hline \multirow[t]{2}{*}{ Labour } & $0.556^{a}$ & $0.556^{a}$ & & \\
\hline & $(0.019)$ & $(0.019)$ & & \\
\hline \multirow[t]{2}{*}{$\mathrm{FDI}^{\text {other }}$} & $0.043^{a}$ & $0.047^{a}$ & $0.046^{a}$ & $0.049^{a}$ \\
\hline & $(0.012)$ & $(0.012)$ & $(0.012)$ & $(0.012)$ \\
\hline \multirow{2}{*}{$\mathrm{FDI}^{\text {other }} \times \mathrm{EFD}_{\mathrm{US}}^{1980}$} & $-0.097^{a}$ & & $-0.099^{a}$ & \\
\hline & $(0.025)$ & & $(0.027)$ & \\
\hline \multirow{2}{*}{$\mathrm{FDI}^{\text {other }} \times \mathrm{EFD}_{\mathrm{US}}^{1980}$ dummy } & & $-0.067^{a}$ & & $-0.067^{a}$ \\
\hline & & $(0.016)$ & & $(0.016)$ \\
\hline \multirow[t]{2}{*}{ Constant } & $0.723^{a}$ & $0.756^{a}$ & $2.834^{a}$ & $2.867^{a}$ \\
\hline & $(0.141)$ & $(0.141)$ & $(0.078)$ & $(0.080)$ \\
\hline Number of observations & 30219 & 30219 & 30219 & 30219 \\
\hline Number of firms & 9435 & 9435 & 9435 & 9435 \\
\hline R-Squared & 0.256 & 0.256 & 0.054 & 0.055 \\
\hline
\end{tabular}

Robust standard errors clustered at the firm level in parenthesis. ${ }^{a},{ }^{b},{ }^{c}$ significantly different from 0 at 1, 5 and 10 percent level respectively. All regressions include firm and year fixed effects. Capital is measured as the real value of tangible fixed assets. Labour is measured as the number of employees. $\mathrm{FDI}^{\text {other }}$ is measured as the total value-added from foreign firms originating elsewhere in an industry-province cell. $\mathrm{EFD}_{\mathrm{US}}^{1980}$ is the external financial dependence index constructed as the share of capital expenditures not financed with cash flows from operation for the median publiclylisted firm in each 3-digit industry in the United States averaged over the 1980s. EFD $\mathrm{US}^{1980}$ dummy is created at the median of the $\mathrm{EFD}_{\mathrm{US}}^{1980}$ index, i.e. 0.21. Total Factor Productivity is calculated using the Levinsohn and Petrin (2003) approach. 


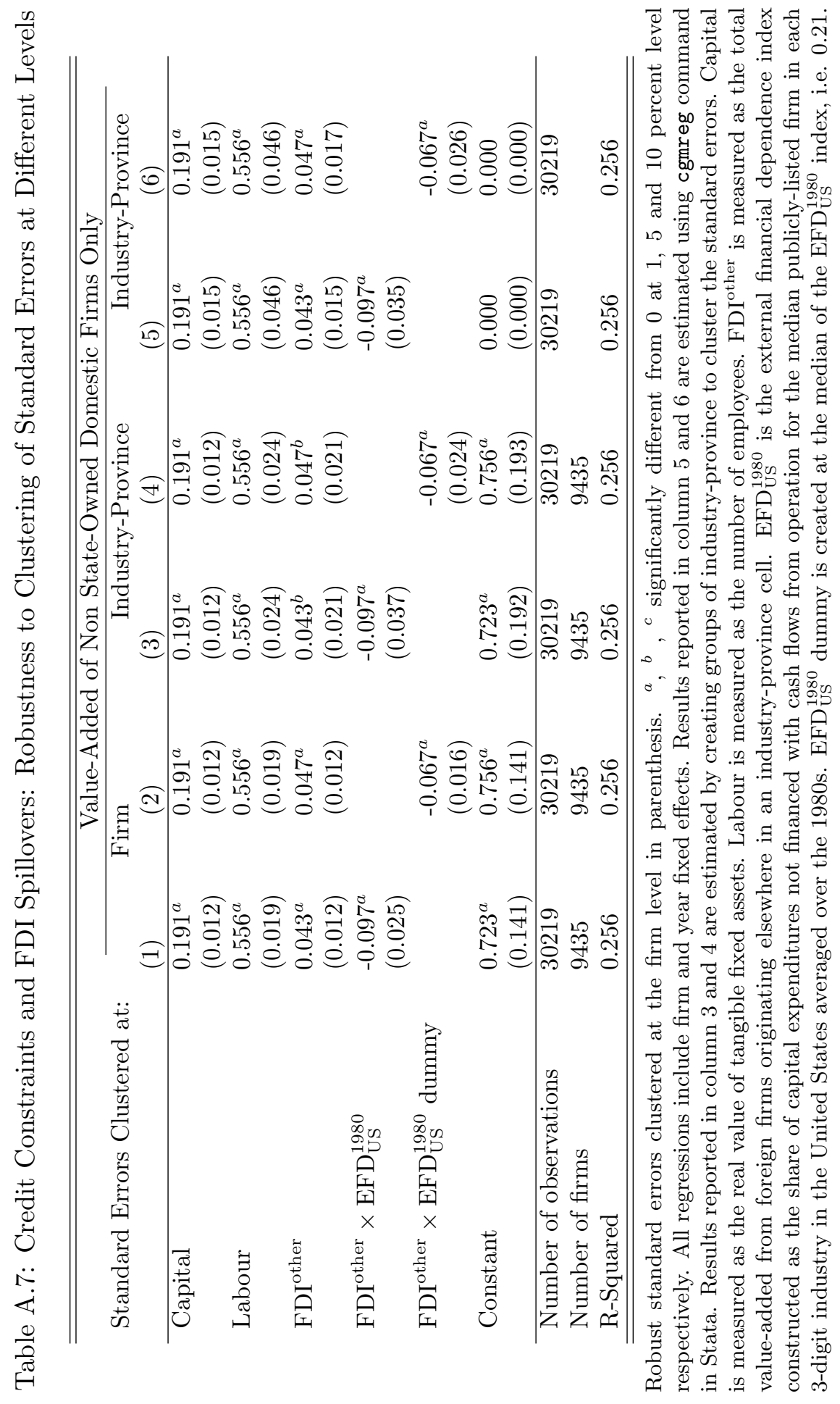


Table A.8: FDI Spillovers: Robustness to Varying Production Function For All Industries

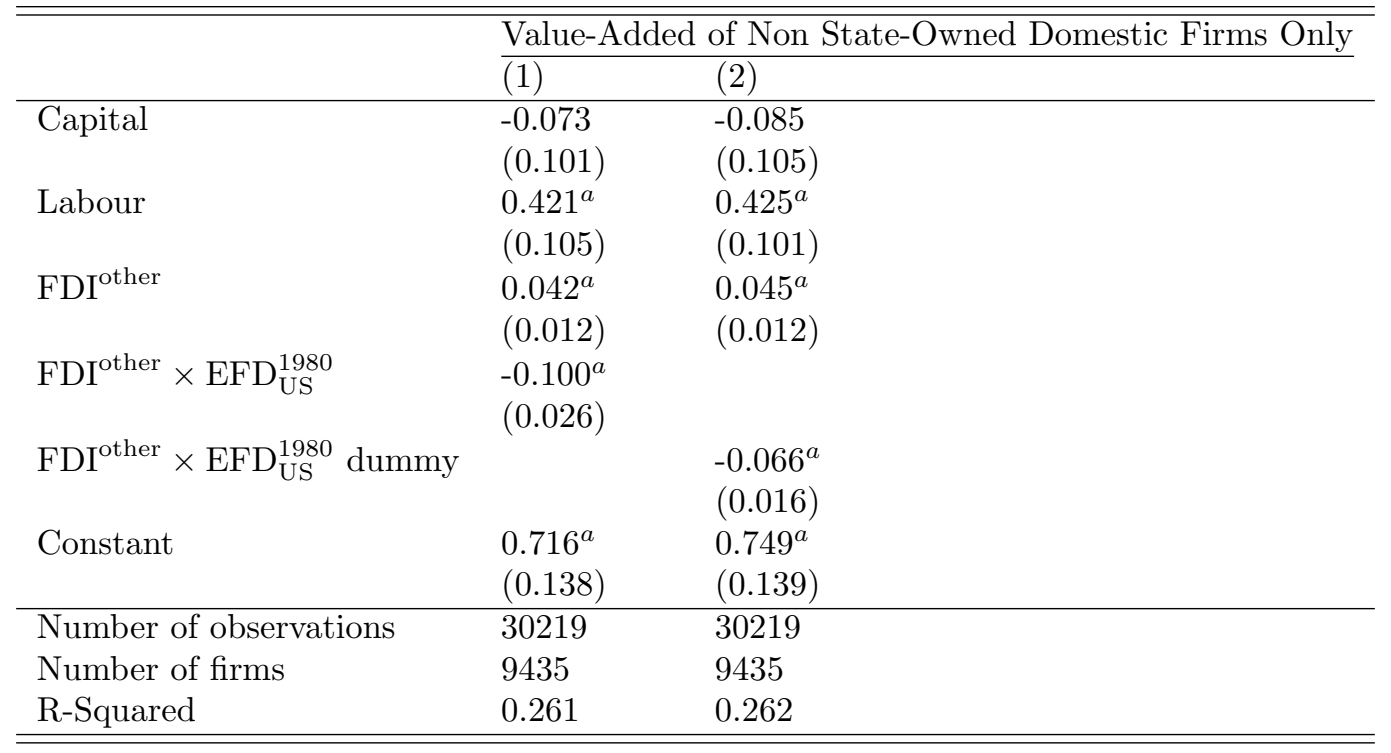

Robust standard errors clustered at the firm level in parenthesis. ${ }^{a},{ }^{b},{ }^{c}$ significantly different from 0 at 1 , 5 and 10 percent level respectively. All regressions include firm, year, industry $\times$ capital, and industry $\times$ labour fixed effects. Capital is measured as the real value of tangible fixed assets. Labour is measured as the number of employees. FDI $^{\text {other }}$ is measured as the total value-added from foreign firms originating elsewhere in an industry-province cell. $\mathrm{EFD}_{\mathrm{US}}^{1980}$ is the external financial dependence index constructed as the share of capital expenditures not financed with cash flows from operation for the median publicly-listed firm in each 3-digit industry in the United States averaged over the $1980 \mathrm{~s}$. $\mathrm{EFD}_{\mathrm{US}}^{1980}$ dummy is created at the median of the $\mathrm{EFD}_{\mathrm{US}}^{1980}$ index, i.e. 0.21 . 
Table A.9: Continuous Interaction Model over Exogenous Sample Splitting

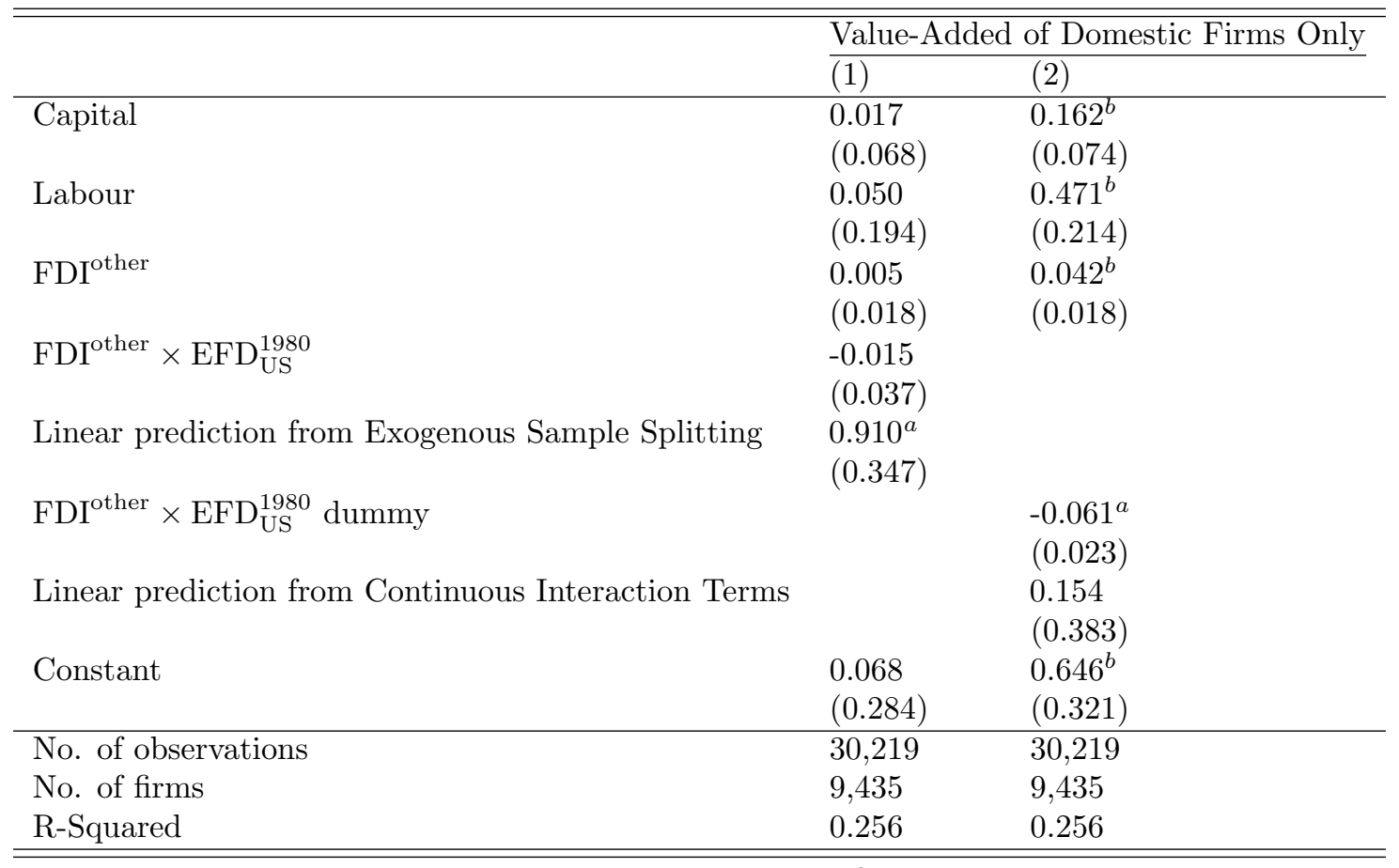

Robust standard errors clustered at the firm level in parenthesis. ${ }^{a},{ }^{b},{ }^{c}$ significantly different from 0 at 1,5 and 10 percent level respectively. Capital is measured as the real value of tangible fixed assets. Labour is measured as the number of employees. FDI ${ }^{\text {other }}$ is measured as the total value-added from foreign firms originating elsewhere in an industry-province cell. $\mathrm{EFD}_{\mathrm{US}}^{1980}$ is the external financial dependence index constructed as the share of capital expenditures not financed with cash flows from operation for the median publicly-listed firm in each 3-digit industry in the United States averaged over the 1980s. EFD $\mathrm{US}_{\mathrm{US}}^{1980}$ dummy is created at the median of the EFD $\mathrm{US}_{\mathrm{S}}^{1980}$ index, i.e. 0.21 . 


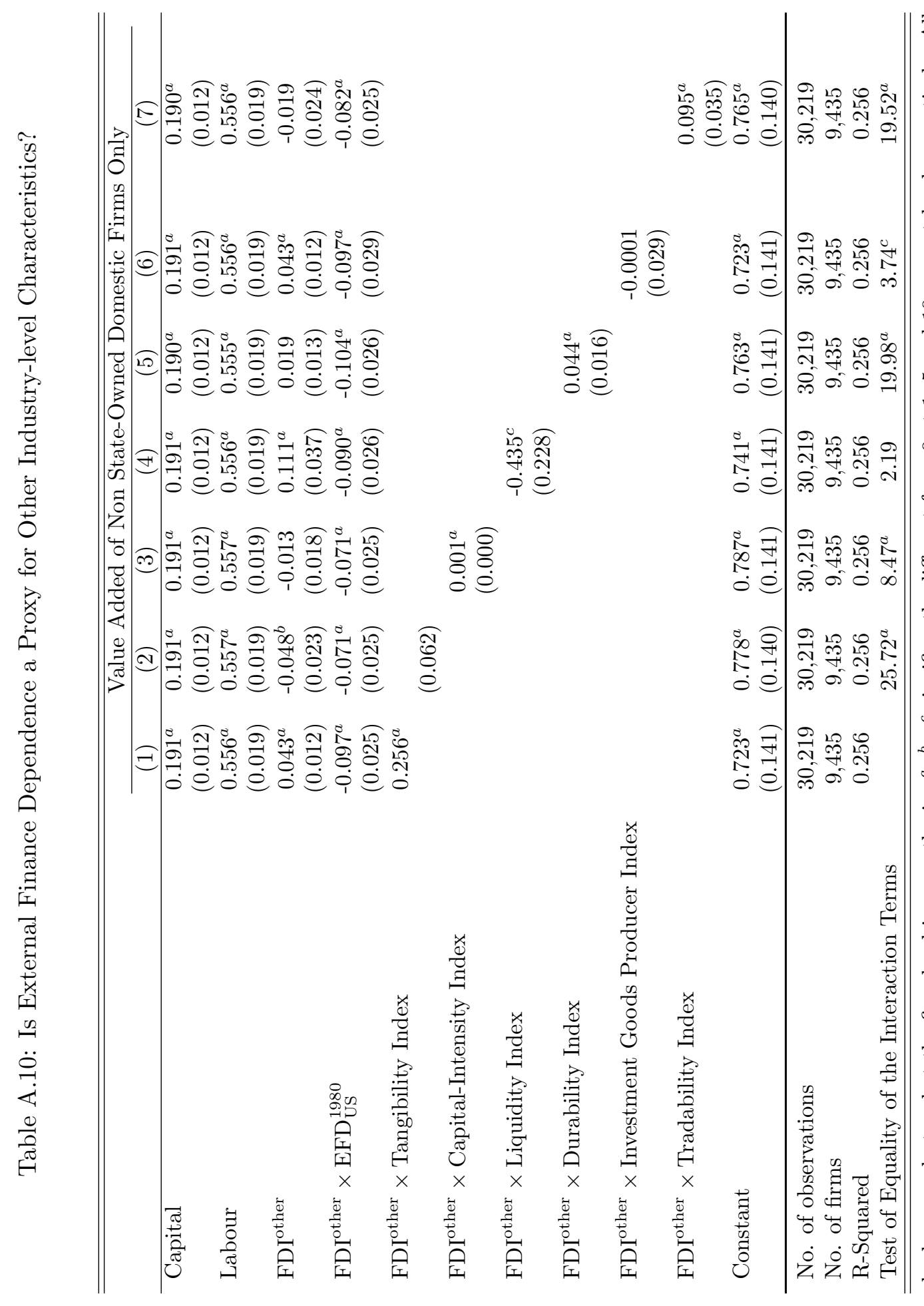

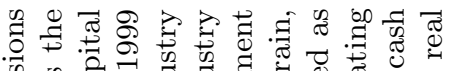

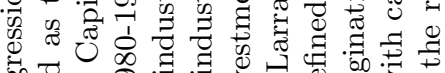

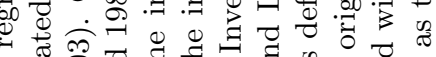

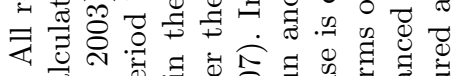

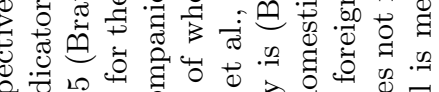

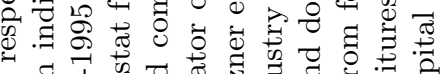

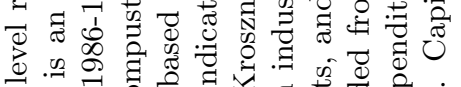

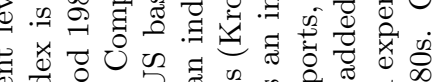

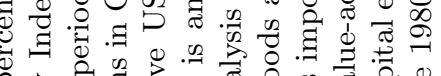

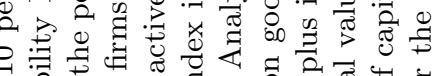

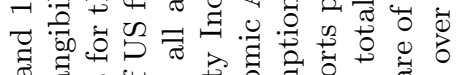

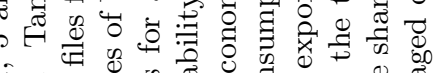

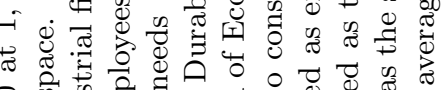
की

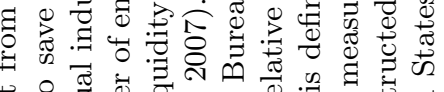

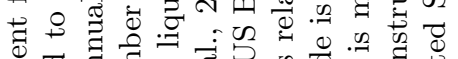

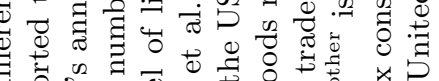

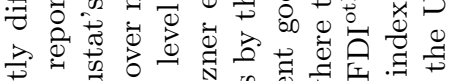

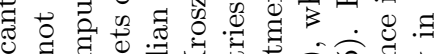

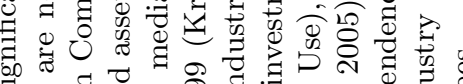
品

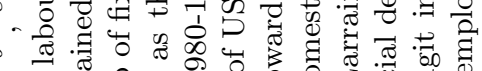

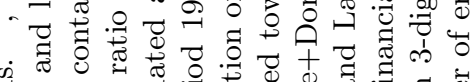

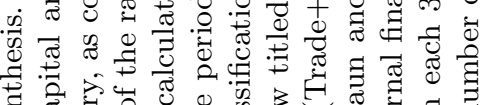

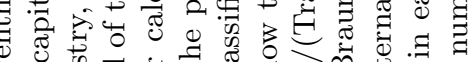

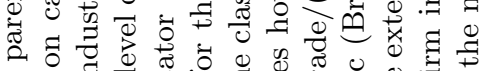
a n

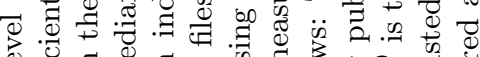
จ.

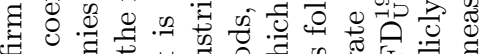

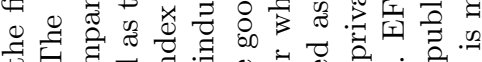

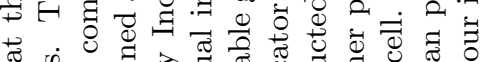

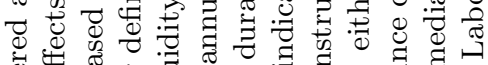

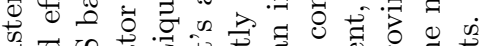

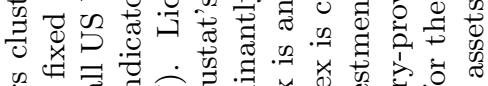

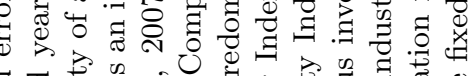

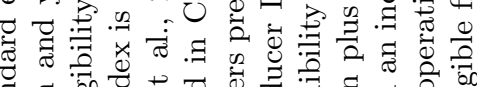

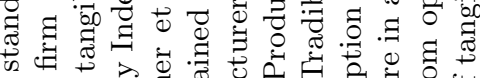
n

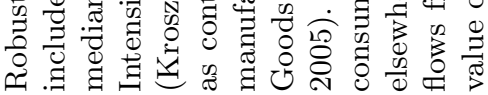

